\title{
The expression of the IGF system in the bovine uterus throughout the oestrous cycle and early pregnancy
}

\author{
R S Robinson ${ }^{1}$, G E Mann², T S Gadd ${ }^{1}$, G E Lamming ${ }^{2}$ and \\ D C Wathes ${ }^{1}$ \\ ${ }^{1}$ Department of Veterinary Basic Sciences, Royal Veterinary College, Hawkshead Road, Potters Bar, Hertfordshire, EN6 1NB, UK \\ ${ }^{2}$ Division of Animal Physiology, School of Biological Sciences, University of Nottingham, Sutton Bonington, Loughborough, Leicestershire, LE12 5RD, UK \\ (Requests for offprints should be addressed to D C Wathes; Email: dcwathes@rvc.ac.uk)
}

\begin{abstract}
The IGF system is expressed in the uterus during the oestrous cycle and early pregnancy and is likely to play an important role in regulating the development of the embryo and uterus. The IGF peptides (IGF-I and -II) mediate their effects through the type 1 IGF receptor (IGF-1R), while the IGF-binding proteins (IGFBP-1 to -6) modulate their interaction with the receptor. In this study, the expression of the IGF system in the bovine uterus was determined throughout the oestrous cycle and on day 16 of pregnancy.

Endometrial biopsy samples were collected from four cows over three cycles such that there were samples for every 2 days from day 0 (oestrus) to day 14 and then every day until day 21. To assess the effect of pregnancy, uterine horn cross-sections were collected on day 16 from 15 pregnant (PREG), five inseminated non-pregnant (INP) and nine uninseminated cyclic controls (CONT). The expression of mRNA for the IGFs, IGF-1R and IGFBP-1 to -5 was determined by in situ hybridisation and the results were quantified by measuring the optical density units from autoradiographs. The main region of IGF-I mRNA expression was the sub-epithelial stroma underlying the luminal epithelium. The expression of IGF-I mRNA was highest at oestrus and lowest during the early and late luteal phases. On day 16, IGF-I mRNA levels were low in all groups, with pregnancy having no effect on
\end{abstract}

the IGF-I mRNA concentrations. The strongest expression of IGF-II mRNA was in the caruncular stroma, with pregnancy having no significant effect in this region. IGF-1R mRNA was also present in the caruncles and was strongly expressed in all epithelial cells both throughout the oestrous cycle and during early pregnancy. The expression of IGFBP-1 mRNA was confined to the luminal epithelium, with the strongest expression seen on day 14 of the cycle. On day 16 the expression of IGFBP-1 mRNA was higher in the PREG group compared with the CONT group. The expression of IGFBP-2 mRNA was localised to the sub-epithelial stroma with more INP than PREG cows showing detectable levels of IGFBP-2. The strongest expression of IGFBP-3 mRNA was in the caruncular stroma; expression in the endometrial stroma was similarly decreased during early pregnancy. IGFBP-5 mRNA was mainly expressed in the inner ring of myometrium and was not affected by pregnancy on day 16.

In conclusion, these results show that many components of the uterine IGF system are differentially regulated during the oestrous cycle and early pregnancy and suggest that modulation of the IGF system may influence uterine activity during this period.

Journal of Endocrinology (2000) 165, 231-243

\section{Introduction}

Insulin-like growth factors (IGF)-I and -II are single chain polypeptides which are structural analogues of proinsulin. IGF-I and -II promote DNA synthesis, cell proliferation and differentiation as well as having acute anabolic effects on protein and carbohydrate metabolism (Jones \& Clemmons 1995, Hossner et al. 1997). IGF-I and -II are expressed in the bovine uterus (Geisert et al. 1991, Kirby et al. 1996) and conceptus (Watson et al. 1992) and are also present in ovine uterine luminal fluid (Ko et al. 1991)

during the pre-implantation period. During this time the ruminant embryo is free living in utero and is dependent on the maternal glandular secretions for all metabolic requirements. The embryo undergoes elongation beginning on day 12. This is associated with the production of the anti-luteolytic hormone interferon-tau (IFN- $\tau$ ) (Farin et al. 1990). IGF-I and -II have been shown to stimulate embryonic production of IFN- $\tau$ in vitro (Ko et al. 1991) and it is likely that IGF-I and -II play an important role in development of both the embryo and uterus during early pregnancy (Wathes et al. 1998). The actions of IGF-I and 
-II are mediated through the IGF type 1 receptor (IGF1R). IGF-1R has been localised to the pre-implantation embryo (Watson et al. 1992) and to the glandular epithelium of the ovine uterus (Stevenson et al. 1994, Reynolds et al. 1997a) supporting a role for IGFs in embryonic and uterine development.

The actions of IGFs are modulated by the IGF-binding proteins (IGFBPs) of which there are at least six different proteins (reviews: Jones \& Clemmons 1995, Hossner et al. 1997). In the circulation, IGFs are predominately carried by IGFBP-3, which establishes and maintains a large circulatory pool of IGF. The IGFBPs are able to target the IGFs to a particular tissue. In the target tissue the IGFBPs generally attenuate IGF activity by preventing IGF interacting with its surface receptors, although stimulatory effects for IGFBP-1, $-2,-3$ and -5 have been reported. IGFBPs are able to associate with cells, IGFBP-1 and -2 to the $\alpha_{5} \beta_{1}$ integrin receptor (Jones et al. 1993a), IGFBP-3 with glucosaminoglycans and IGFBP-5 to collagen, laminins and fibronectin components of the extracellular matrix (Jones et al. 1993b). The cell-associated IGFBP has reduced affinity for the IGF, thereby enhancing IGF delivery to IGF-1R. Target cells can also increase the IGF bioavailability by either dephosphorylation of IGFBP-1 or proteolytic cleavage of the IGFBPs.

The current calving rate per insemination for dairy cows is less than $55 \%$ with a substantial loss of embryos occurring between days 1 and 42 (Peters 1996). In cattle, poor fertility may in part be due to the cow at service being in negative energy balance as the energy requirement for lactation at this stage is higher than can be supported by feed intake, particularly in high-yielding cows (Kruip et al. 1998). Many components of the IGF system are modulated by nutrition; for example serum IGF-I is decreased during dietary energy restrictions (Thissen et al. 1994). It is possible that the poor fertility seen during negative energy balance may in part be due to an inadequate IGF system within the uterine environment.

Previous studies have shown that around maternal recognition of pregnancy in cows the expression of both IGF-I and -II mRNA was increased, while IGFBP-3 mRNA was decreased in pregnant (PREG) endometrium (Geisert et al. 1991, Kirby et al. 1996, Keller et al. 1998). In the present study we have extended these findings on the expression of the IGF system in the bovine uterus by examining the localisation of most of the components throughout the oestrous cycle and during early pregnancy. This should aid our understanding of the regulation of the uterine IGFs and the role that the IGF system may play in the establishment of pregnancy in cows.

\section{Materials and Methods}

\section{Animals}

Experiment 1 Endometrial biopsy samples were collected over three oestrous cycles from four Friesian/
Holstein non-lactating cows as described by Mann \& Lamming (1994). The biopsy samples were collected on days $14,15,16,17$ and 18 over the first cycle; days 6,8 , 10 and 12 over the second cycle and days 0 (oestrus), 2, 4, 19, 20 and 21 over the third cycle. The samples were frozen immediately in isopentane in liquid nitrogen and stored at $-80{ }^{\circ} \mathrm{C}$ for subsequent analysis. Blood samples were collected daily from the jugular vein for subsequent oestradiol and progesterone analysis.

Experiment 2 Twenty-nine barren Friesian/Holstein cows at the end of lactation were synchronised with two injections of estrumate (prostaglandin $\mathrm{F}_{2 \alpha}$ analogue; Coopers Animal Health, Crewe, Cheshire, UK) 12 days apart. The cows were then doubly inseminated 72 and $96 \mathrm{~h}$ after the second prostaglandin injection or left as controls. The cows were slaughtered on day 16 and the uterus flushed for embryos. Uterine cross-sections, approximately $5 \mathrm{~cm}$ in length were taken and frozen in isopentane in liquid nitrogen and stored at $-80{ }^{\circ} \mathrm{C}$ for subsequent analysis. In PREG animals the cross-sections were taken from the horn with the embryo present.

\section{Oligonucleotide probes}

All probes used were single-stranded oligonucleotides 45 bases in length (Brabaham Institute, Cambridge, UK). Sense probes were always included as negative controls and any signal from these was regarded as non-specific (Table 1).

\section{Localisation of $m R N A$ by in situ hybridisation}

The method was based upon that previously described by Stevenson et al. (1994). Sections $(10 \mu \mathrm{m}$ thick) were cut and thaw mounted onto $1 \mathrm{mg} / \mathrm{ml}$ poly-L-lysine $\left(M_{\mathrm{r}}>300000\right)$ coated glass slides. The sections were fixed in $4 \%(\mathrm{w} / \mathrm{v})$ paraformaldehyde in $0.01 \mathrm{M}$ PBS, $\mathrm{pH} 7 \cdot 0$ for $5 \mathrm{~min}$ at room temperature and then washed three times with $0.01 \mathrm{M}$ PBS. The slides were sequentially dehydrated in ethanol and stored at $4{ }^{\circ} \mathrm{C}$ in $95 \%$ ethanol. The oligonucleotide (5 ng) was end-labelled with $\left[{ }^{35} \mathrm{~S}\right]$ dATP (Amersham International, Aylesbury, Bucks, UK) using deoxynucleotidyl transferase (Pharmacia Biotech, St Albans, Herts, UK) at $34{ }^{\circ} \mathrm{C}$ for $1 \mathrm{~h}$. The labelled probe was diluted to a final concentration of 1100000 c.p.m. $/ \mathrm{ml}$ in hybridisation buffer $(50 \%$ (v/v) deionised formamide, $4 \times \mathrm{SSC}, 25 \mathrm{mM}$ sodium phosphate, $1 \mathrm{mM}$ sodium pyrophosphate, $5 \times$ Denhardt's solution, $0.2 \mathrm{mg} / \mathrm{ml}$ denatured salmon sperm DNA, $120 \mu \mathrm{g} / \mathrm{ml}$ sodium heparin, $100 \mu \mathrm{g} / \mathrm{ml}$ polyadenylic acid and $100 \mathrm{mg} / \mathrm{ml}$ dextran sulphate) and $100 \mu \mathrm{l}$ added to each section. The sections were incubated in a humidified box at $42.5{ }^{\circ} \mathrm{C}$ overnight. The slides were washed in $1 \times \mathrm{SSC}, 2 \mathrm{~g} / 1$ sodium thiosulphate at room temperature for $30 \mathrm{~min}$, then in fresh $1 \times \mathrm{SSC}, 0.2 \mathrm{~g} / 1$ sodium 
Table 1 The sequence of the sense probes and exposure time for in situ hybridisation X-ray films and emulsions

\begin{tabular}{|c|c|c|c|c|}
\hline \multirow[b]{3}{*}{ Probe } & \multirow[b]{2}{*}{ Sense sequence } & \multicolumn{2}{|c|}{ Exposure time (days) } & \multirow{2}{*}{$\begin{array}{l}\text { Homology to } \\
\text { bovine gene } \\
(\%)\end{array}$} \\
\hline & & X-ray film & Emulsions & \\
\hline & & & & \\
\hline IGF-I & $\begin{array}{l}\text { 82-126 of ovine IGF-I gene (Wong et al. 1989) } \\
5^{\prime} \text { GTC ACA TCC TCC TCG CAT CAC TTC TAT CTG GCC CTG TGC TTG CTC } 3^{\prime}\end{array}$ & 18 & 24 & 98 \\
\hline IGF-II & $\begin{array}{l}\text { 352-396 of ovine IGF-II gene (O'Mahoney \& Adams } 1989 \text { ) } \\
\text { 5' CCA GCG AGA CTC TGT GCG GCG GGG AGC TGG TGA CAC CCT CCA GTT 3' }\end{array}$ & 18 & 24 & 100 \\
\hline IGF-1R & $\begin{array}{l}\text { 338-382 of human IGF-1R gene (Ullich et al. 1986) } \\
\text { 5' CTC ACG GTC ATC CGC GGC TGG AAA CTC TTC TAC AAC TAC GCC CTG 3' }\end{array}$ & 18 & 24 & $\mathrm{ND}^{*}$ \\
\hline IGFBP-1 & $\begin{array}{l}\text { 779-823 of bovine IGFBP-1 gene (Sneyers et al. 1991) } \\
\text { 5' GGA GAG CCT GGG CTC TGT TGG TGT GTC TAC CCT TGG AGT GGG AAG 3' }\end{array}$ & 24 & 36 & 100 \\
\hline IGFBP-2 & $\begin{array}{l}\text { 487-531 of bovine IGFBP-2 gene (Bourner et al. 1992) } \\
5^{\prime} \text { GAG GTG CTG TTC CGC TGC CCG CCC TGC ACG CCC GAG AGC CTG GCC 5' }\end{array}$ & 30 & 42 & 100 \\
\hline IGFBP-3 & $\begin{array}{l}\text { 534-578 of bovine IGFBP-3 gene (Spratt et al. 1991) } \\
\text { 5' GAG AGC GAG GAG GAC CAC AGC ATG GGG AGC ACA GAG AAC CAG GCC 3' }\end{array}$ & 24 & 36 & 100 \\
\hline IGFBP-4 & $\begin{array}{l}\text { 118-162 of ovine IGFBP-4 gene (Shimasaki \& Ling 1991) } \\
\text { 5' CTG GGC AAG GGA ATG CGC TGT GGG GTG TAC ACC CCC GAC TGC GGC 3' }\end{array}$ & 30 & 42 & 91 \\
\hline IGFBP-5 & $\begin{array}{l}\text { 291-335 of bovine IGFBP-5 gene (Moser et al. 1992) } \\
\text { 5' CTA CTC GCC CAA GAT CTT CCG GCC CAA GCA CAC CCG CAT CTC CGA 3' }\end{array}$ & 14 & 21 & 100 \\
\hline
\end{tabular}

*ND: This region of the bovine gene has not been determined yet, but the region selected is highly homologous between other species.

thiosulphate at $57 \cdot 5{ }^{\circ} \mathrm{C}$ for $60 \mathrm{~min}$. The sections were washed for $1 \mathrm{~min}$ in $1 \times \mathrm{SSC}, 0 \cdot 1 \times \mathrm{SSC}, 75 \%$ ethanol and $95 \%$ ethanol and air-dried. The slides were exposed to $\beta$-max hyperfilm (Amersham International) for the time indicated in Table 1.

\section{Photographic emulsions}

Slides previously exposed to X-ray film were coated with photographic emulsion LM1 (Amersham International) according to the manufacturer's instructions and left at $4{ }^{\circ} \mathrm{C}$ for the time indicated in Table 1 . The slides were developed in $20 \%$ phenisol, fixed in $1.9 \mathrm{M}$ sodium thiosulphate and counterstained with haematoxylin and eosin to confirm cellular localisation of the radioactive signal.

\section{Optical density (OD) measurements}

OD measurements were made using a Seescan image analysis system (Seescan plc, Cambridge, UK) as described by Stevenson et al. (1994). In brief, autoradiographs were projected onto a computer screen, the region of interest was encircled and the OD reading was measured. The background OD, from a blank autoradiograph, was first automatically subtracted. The OD value for the sense section was subtracted from the corresponding antisense section. Readings were obtained from two sections per cow and a mean value of specific hybridisation for each animal was then calculated. The limit of detection was taken as an OD value of $0 \cdot 01$. Coefficients of variation between two separate slides for duplicate absorbance measurements were as follows: IGF-I, 12.9\%; IGF-II, $17 \cdot 5 \% ;$ IGF-1R, 9.2\%; IGFBP-1, $13 \cdot 6 \%$; IGFBP-2,
18.9\%; IGFBP-3, 12.7\%; and IGFBP-5, 13.5\%. In Experiment 1 , all sections from the same cow treated with a particular probe were analysed in the same batch. In Experiment 2, sections from all animals treated with a particular probe were analysed together.

\section{Statistical analysis}

The data were subjected to ANOVA using the general linear model procedures of SPSS version 7·0. The data were tested for heterogeneity of variance by Levene's test and $\log$ transformed if appropriate. In Experiment 1, the data were analysed by randomised block ANOVA with day as the fixed factor and cow as the random factor. The error degrees of freedom were adjusted for the repeated measures design using the Greenhouse-Geisser epsilon value. The concentrations of the same probe in different regions were compared using a paired $t$-test. In Experiment 2, the data were analysed by one-way ANOVA followed by Fisher's least significant difference multiple comparison to elucidate where differences lay. A nonparametric Kruskal-Wallis ANOVA was performed on data for IGF-II mRNA in the caruncular stroma as the data did not show a normal distribution. The numbers of animals which were expressing detectable levels of IGF-I and IGFBP-2 mRNA between PREG and inseminated non-pregnant (INP) groups were compared using Fisher's exact test. All data are presented as OD units \pm S.E.M.

\section{Results}

The bovine uterine endometrium consists of stromal tissue lined by a luminal epithelium and penetrated by glands. 

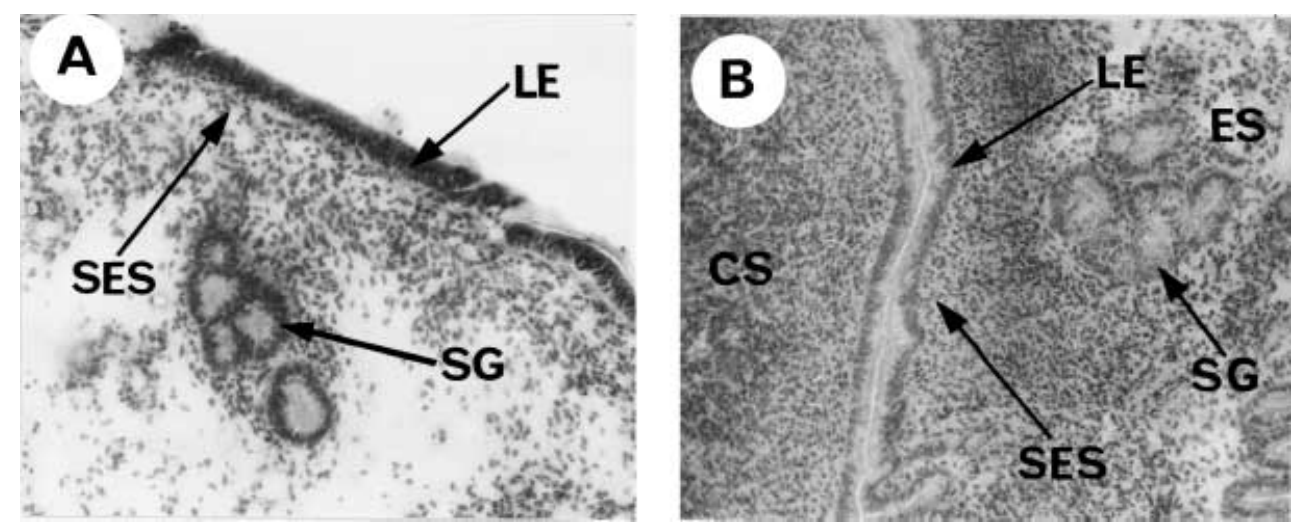

Figure 1 (A) Cryostat section of a bovine endometrial biopsy sample obtained on day 0 (oestrus) of the oestrous cycle stained with haematoxylin and eosin to show the morphology of the different regions examined. LE, luminal epithelium; SG, superficial glands; SES, sub-epithelial stroma underlying the luminal epithelium. (B) Cryostat section of bovine uterine horn cross-section obtained on day 16 of pregnancy stained with haematoxylin and eosin to show the morphology of the different regions examined. CS, caruncular stroma; ES, endometrial stroma. The sections also contained deep glands and myometrium (not shown). Magnification A $\times 300, \mathrm{~B} \times 180$.

Three regions of the stroma can be distinguished: the sub-epithelial stroma, a band of dense connective tissue underlying the luminal epithelium; the caruncular stroma, dense connective tissue forming the caruncles (preferred areas of placental attachment) and the endometrial stroma, the loose connective tissue between the luminal epithelium and myometrium. The glands nearest to the lumen are termed superficial glands, whilst those adjacent to the myometrium are the deep glands. The endometrial biopsy samples collected in Experiment 1 routinely only included luminal epithelium, sub-epithelial stroma and superficial glands (Fig. 1A). They also occasionally contained caruncular stroma and myometrium. The complete uterine horn cross-sections available in Experiment 2 contained the following regions: luminal epithelium, subepithelial stroma, superficial glands, deep glands, endometrial stroma and myometrium. Caruncular stroma was also present in some cross-sections (Fig. 1B).

\section{Expression of IGF-I $m R N A$}

IGF-I mRNA was localised to the sub-epithelial stroma underlying the luminal epithelium throughout the oestrous cycle and during early pregnancy (Figs 2A and $3 A)$. IGF-I mRNA was expressed in a cyclical manner $(P=0 \cdot 05)$ with the highest expression observed during oestrus. Immediately after oestrus, IGF-I mRNA levels fell to a nadir on day 2 , gradually rose to a lower peak around day 10, then declined again by day 16 (Fig. 4). On day 16 of pregnancy, low levels of IGF-I mRNA in the subepithelial stroma were detectable (i.e. OD $>0 \cdot 01$ ) in 9 out of 15 PREG (OD 0.04 $\pm 0 \cdot 01)$ compared with only 1 out of 5 INP animals $(P=0 \cdot 14)$ and in 3 out of 9 cyclic control (CONT) cows. In all other animals expression was below the detection limit of $0 \cdot 01$. IGF-I mRNA was also expressed in the stroma and myometrium in all animals but at very low levels (Fig. 3A).

\section{Expression of IGF-II $m R N A$}

On day 16 of pregnancy, the strongest expression of IGF-II mRNA was observed in the caruncular stroma (Figs 2B and 3B). Caruncles were generally not present in the endometrial biopsy samples and so IGF-II mRNA expression through the cycle was not investigated. IGF-II mRNA was also expressed in the endometrial stroma, myometrium and in the glands, although at much lower levels (Fig. 2B). PREG animals showed lower IGF-II mRNA expression in the endometrial stroma and myometrium compared with the CONT day 16 animals $(P<0 \cdot 05)$ but were not different from the INP group (Fig. 5).

\section{Expression of IGF-1R $m R N A$}

IGF-1R mRNA was expressed at moderate levels in the luminal epithelium and at higher levels in the superficial glands $(P<0 \cdot 001)$ (Figs 2C and 3C). Concentrations of IGF-1R in these regions were relatively constant throughout the oestrous cycle $(P>0 \cdot 05)$, although the highest expression was seen on day 8 in the luminal epithelium and on day 10 in the superficial glands (Fig. 6A). On day 16 of pregnancy, IGF-1R mRNA was expressed in all epithelial cells with the strongest expression observed in the deep glands next to the myometrium $(P<0.001$ versus the luminal epithelium) (Fig. 2C). There were no significant differences between the PREG, CONT and INP 

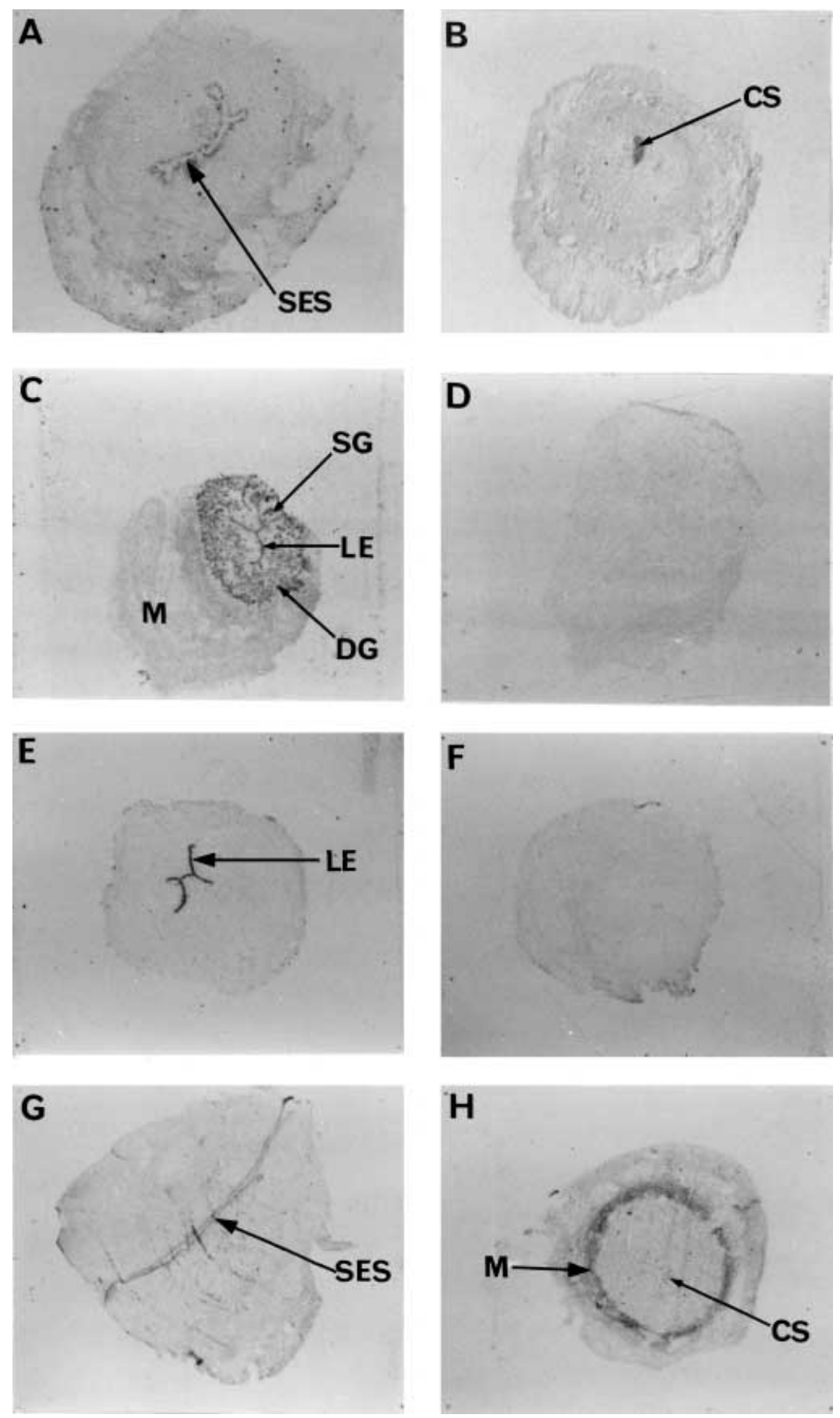

Figure 2 The localisation of mRNA encoding components of the IGF system in the day 16 PREG bovine uterus. The photographs are complete uterine horn cross-sections from autoradiographs showing the distribution of (A) IGF-l; (B) IGF-II; (C) IGF-1R; (E) IGFBP-1; (G) IGFBP-2 and (H) IGFBP-5 mRNA. (D and F) Control sections probed with sense oligonucleotides to IGF-1R and IGFBP-1 mRNA respectively. The sense controls for IGF-I, IGF-II, IGFBP-2 and IGFBP-5 were similarly blank (not shown). There was moderate expression of IGF-I mRNA in the sub-epithelial stroma (SES) underlying the luminal epithelium (LE). IGF-II mRNA was strongly expressed in the caruncular stroma (CS). IGF-1R mRNA was present in luminal epithelium, superficial glands (SG), deep glands (DG) and myometrium (M). IGFBP-1 mRNA was strongly expressed in the luminal epithelium, while IGFBP-2 mRNA was localised to the sub-epithelial stroma region underlying the luminal epithelium in some PREG cows. The strongest expression of IGFBP-5 mRNA was observed in the inner ring of myometrium $(\mathrm{M})$, but it was also expressed in the caruncular stroma, although at much lower concentrations. Magnification $\times 2$. 

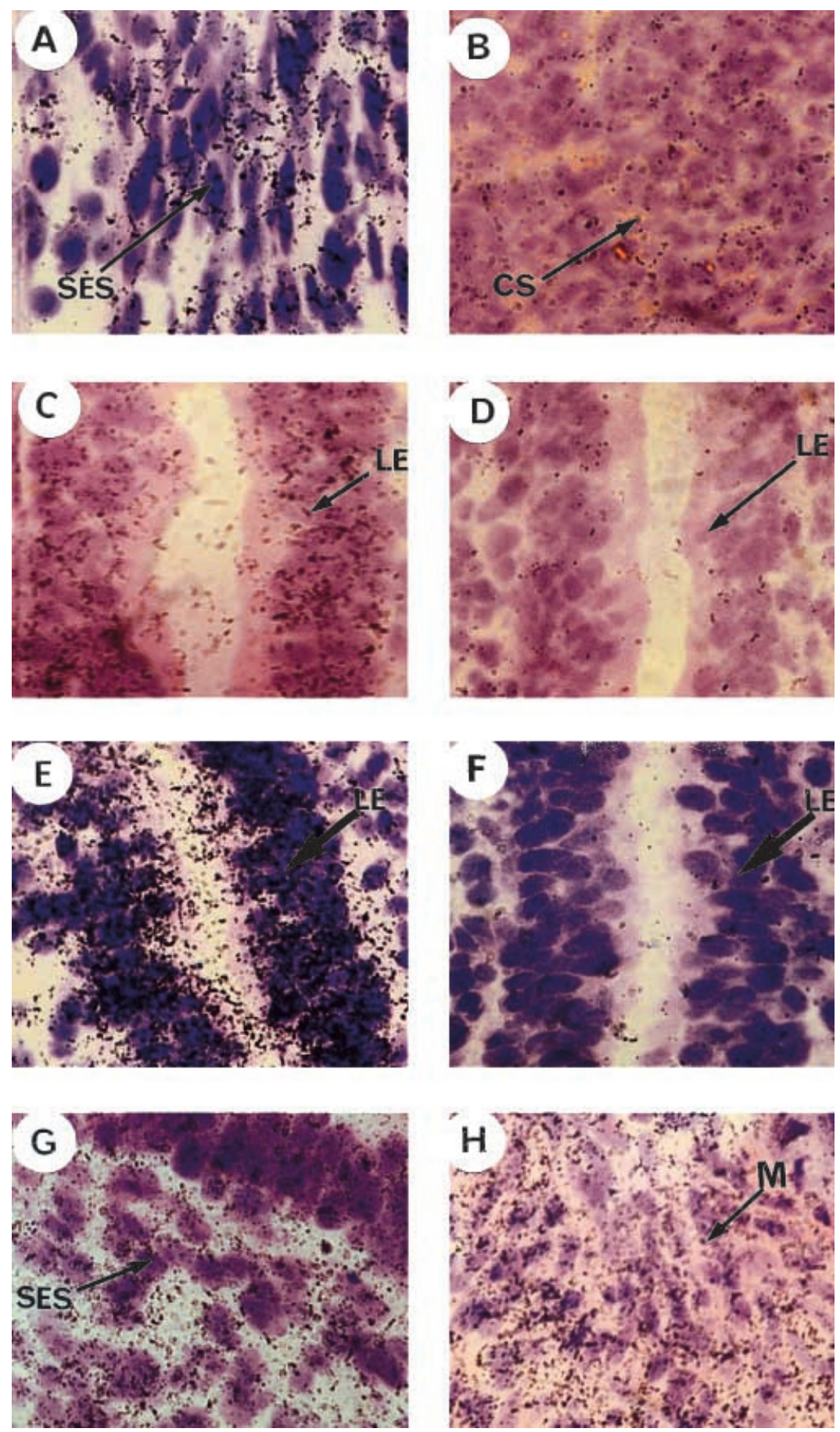

Figure 3 The distribution of the IGF system in the bovine uterus on day 16 of pregnancy. The photographs show sections of uterine horn coated with photographic emulsion and counterstained with haematoxylin and eosin. The cellular localisation of mRNA encoding for (A) IGF-I; (B) IGF-II; (C) IGF-1R; (E) IGFBP-1; (G) IGFBP-2 and (H) IGFBP-5 are shown. The sections were probed with antisense oligonucleotides. (D and F) Show control sections probed with sense oligonucleotides to IGF-1R and IGFBP-1 mRNA respectively. The sense controls for IGF-I, IGF-II, IGFBP-2 and IGFBP-5 were similarly blank (not shown). The silver grains confirmed the localisation for IGF-I mRNA in the sub-epithelial stroma (SES) underlying the luminal epithelium (LE), IGF-II mRNA in the caruncular stroma (CS) and IGF-1R mRNA in luminal epithelium. IGFBP-1 mRNA was strongly expressed in the luminal epithelium, whereas IGFBP-2 mRNA was localised to the sub-epithelial stroma region. The strongest expression of IGFBP-5 mRNA was observed in the inner ring of the myometrium (M). Magnification $\times 1300$. 


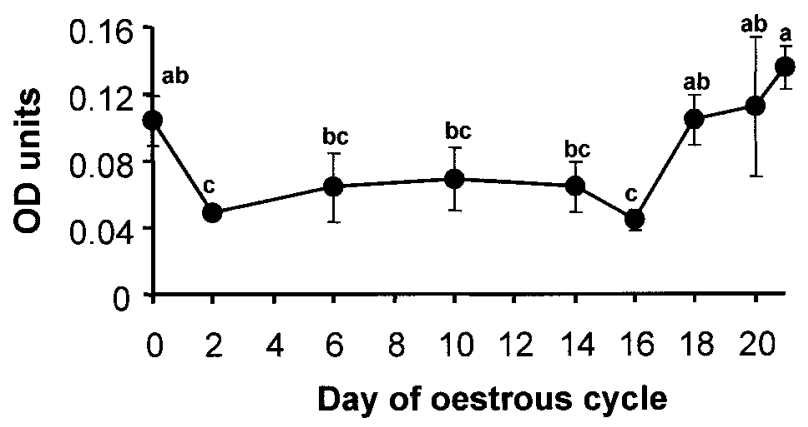

Figure 4 The expression of IGF-I mRNA in the sub-epithelial stroma of endometrial biopsy samples throughout the oestrous cycle. Values are mean OD units \pm S.E.M. ( $n=3-4$ per time point). There was a significant effect of day of cycle (ANOVA). All significant differences are indicated with different letters $(a>b>c)$ $(P<0 \cdot 05)$.

groups in any region (Fig. 6B). IGF-1R mRNA was also expressed in the caruncular stroma at similar levels in all animals.

\section{Expression of IGFBP-1 $m R N A$}

IGFBP-1 mRNA was localised solely to the luminal epithelium in all samples tested (Figs 2E and 3E). IGFBP-1 mRNA was expressed in a cyclical manner throughout the oestrous cycle $(P=0 \cdot 04)$. IGFBP-1 mRNA expression was low but detectable at oestrus in three out of the four cows, but was not detected during the early luteal phase in all cows. IGFBP-1 mRNA concentrations increased between days 8 and 12, peaked on day 14 and then decreased to become not detected again by day 20 (Fig. 7A). On day 16, the expression of IGFBP-1 mRNA was significantly higher in PREG than in CONT cows $(P=0 \cdot 02)$ with intermediate values in the INP group $(P>0 \cdot 05$, Fig. $7 \mathrm{~B})$.

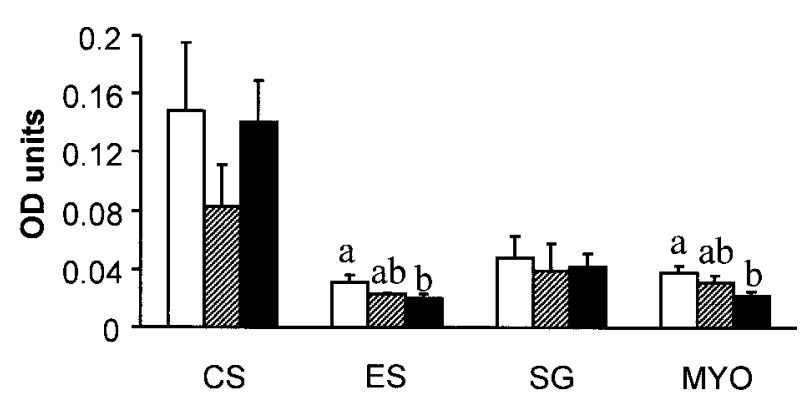

Figure 5 The expression of IGF-II mRNA in the bovine uterus on day 16 measured as OD units. Values are mean OD \pm S.E.M. of CONT (open bars; $n=9$ ), INP (hatched bars; $n=5$ ) and PREG (solid bars; $n=15$ ) cows. The regions shown are caruncular stroma (CS), endometrial stroma (ES), superficial glands (SG) and myometrium (MYO). (a>b, $P<0 \cdot 05)$.
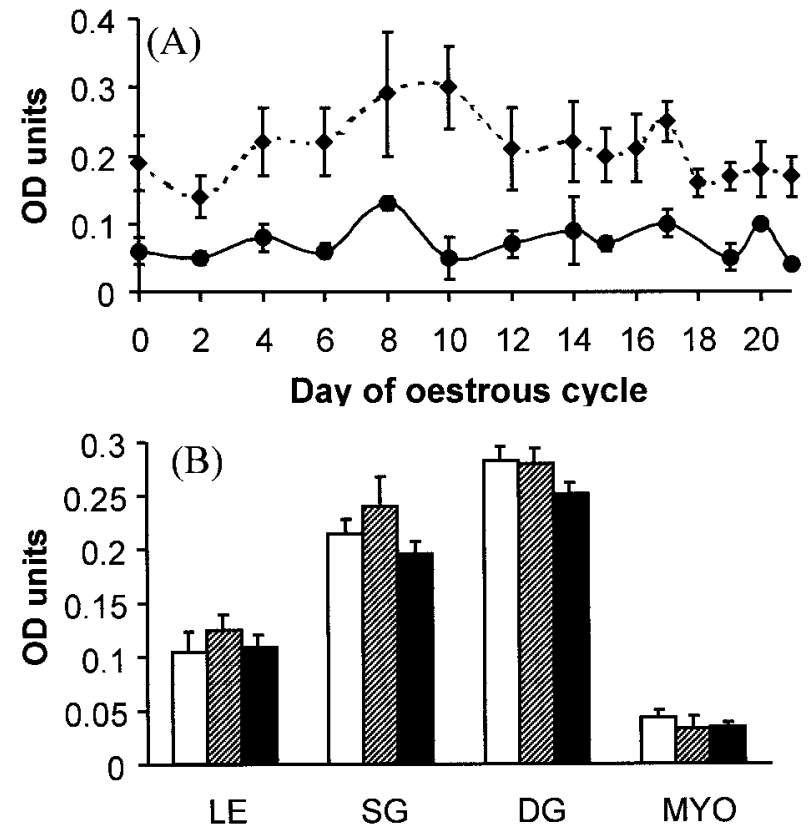

Figure 6 The concentration of IGF-1R mRNA in the bovine endometrium: (A) throughout the oestrous cycle and (B) on day 16 of pregnancy. Values are mean OD units \pm S.E.M. (A) Concentrations of IGF-1R mRNA in the luminal epithelium (continuous line, $\mathbf{)}$ ) and in the superficial glands (dotted line, ) of bovine endometrial biopsy samples throughout the oestrous cycle $(n=3-4$ per time point). There were no significant differences from oestrus (day 0). (B) Expression of IGF-1R mRNA in the bovine uterus from CONT (open bars; $n=9$ ), INP (hatched bars; $n=5$ ) and PREG (solid bars; $n=15$ ) cows in the luminal epithelium (LE), superficial glands (SG), deep glands (DG) and myometrium (MYO). There were no significant differences between the PREG, CONT and INP groups.

Expression of IGFBP-2 and $-4 m R N A$ in the bovine uterus during early pregnancy

The expression of IGFBP-2 mRNA was the last to be analysed, and since there was not enough tissue left in the biopsy sample we were unable to analyse its expression during the cycle. In early pregnancy, low concentrations of IGFBP-2 mRNA were observed in the sub-epithelial stroma underlying the luminal epithelium with expression confined to this region on day 16 (Figs $2 \mathrm{G}$ and $3 \mathrm{G}$ ). Concentrations were detectable in four out of five INP cows compared with only 3 out of 15 PREG animals $(P=0 \cdot 03)$. The CONT group with three out of seven animals expressing detectable levels was not different from the INP or PREG groups. Preliminary attempts to localise IGFBP-4 mRNA using ovine probes showed no hybridisation in the PREG or cyclic bovine uterus on day 16 . Further investigation is required to determine if there was no IGFBP-4 mRNA on day 16 in the bovine uterus or if the ovine probe does not hybridise to the bovine IGFBP-4 mRNA. The homology of the probe to the equivalent region of the bovine gene was $91 \%$. 

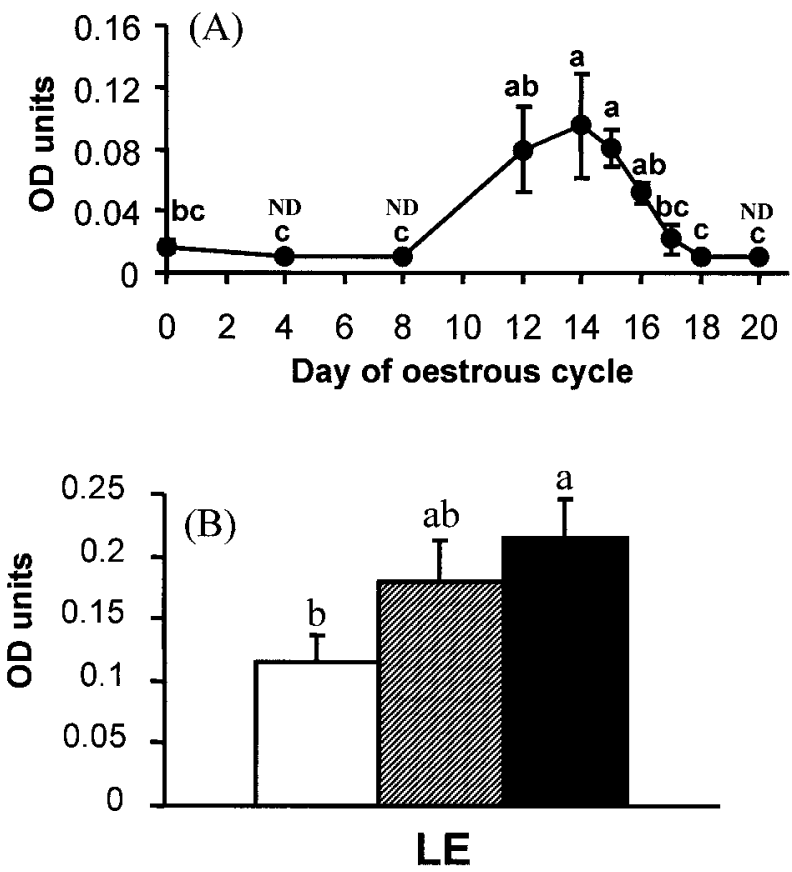

Figure 7 The expression of IGFBP-1 mRNA: (A) throughout the oestrous cycle and (B) on day 16 of pregnancy. Values are mean OD units \pm S.E.M. (A) Concentrations of IGFBP- 1 mRNA in the luminal epithelium of bovine endometrial biopsy samples throughout the oestrous cycle ( $n=3-4$ per time point). There was low expression of IGFBP-1 mRNA at oestrus (day 0) with nondetected levels (ND) on day 4, 8 and 20. All significant differences are indicated with different letters $(a>b>c)(P<0 \cdot 05)$. (B) Expression of IGFBP-1 mRNA in the bovine uterus from CONT (open bars; $n=9$ ), INP (hatched bars; $n=5$ ) and PREG (solid bars; $n=15$ ) cows. The expression of IGFBP-1 mRNA was confined to the luminal epithelium (LE) and was significantly higher $(a>b$; $P<0.05)$ in the PREG than in the CONT group.

\section{Expression of IGFBP-3 $m R N A$}

In Experiment 1, IGFBP-3 mRNA was expressed in the luminal epithelium, sub-epithelial stroma and superficial glands (Fig. 8A and B). There was no significant variation in IGFBP-3 mRNA expression throughout the oestrous cycle in any region $(P>0 \cdot 1)$ (Fig. 9A). This may in part be due to the large variation in endometrial IGFBP-3 mRNA expression between cows. In Experiment 2, IGFBP-3 mRNA was absent from the luminal epithelium (except for one INP cow), sub-epithelial stroma and glandular epithelium, in contrast to the results from Experiment 1 (Fig. 8C). IGFBP-3 mRNA was, however, expressed in the endometrial and caruncular stroma as well as in the myometrium (Fig. 8C and D). IGFBP-3 mRNA expression in the endometrial stroma and myometrium was significantly lower in PREG and INP cows than in the CONT cows $(P<0 \cdot 001)$ (Fig. 9B). IGFBP-3 mRNA was also expressed in the blood vessel walls but this was not quantified.
Expression of IGFBP-5 $m R N A$

The photographic emulsions suggested that there was very low expression of IGFBP-5 mRNA in the glandular epithelium, which was below the detection limit of the Seescan instrument. There was strong IGFBP-5 mRNA expression in the caruncular stroma and myometrium, although these regions were not present in the majority of the biopsy samples and so we were unable to study the expression of IGFBP-5 mRNA throughout the oestrous cycle. On day 16 of pregnancy, the expression of IGFBP-5 mRNA was higher in the inner ring of myometrium compared with the outer ring $(P<0 \cdot 001)$ (Figs $2 \mathrm{H}$ and $3 \mathrm{H})$. IGFBP-5 mRNA was also expressed in the caruncular stroma and sub-epithelial stroma although at low concentrations. On day 16, there was no difference in the expression of the IGFBP- 5 mRNA between the PREG, CONT and INP groups (for example in the inner ring of myometrium CONT 0.06 \pm 0.01 vs INP $0.07 \pm 0.01$ vs PREG $0 \cdot 08 \pm 0 \cdot 01 ; P=0 \cdot 24)$.

\section{Discussion}

In this study, we have determined the expression patterns of the various members of the IGF system in the bovine uterus throughout the oestrous cycle and early pregnancy. The different members of the IGF system were localised to different cell types in the endometrium and expression was also influenced both by the stage of the cycle and by the presence of an embryo.

In the bovine endometrium, the strongest expression of IGF-I mRNA was observed in the sub-epithelial stroma underlying the luminal epithelium, which is in agreement with IGF-I mRNA localisation in the sheep (Stevenson et al. 1994, Reynolds et al. 1997a) and human (Zhou et al. 1994) uterus. The expression of IGF-I mRNA in this region would enable IGF-I to stimulate the proliferation/ differentiation of the luminal epithelium and/or embryo. A number of studies have demonstrated that uterine IGF-I mRNA concentrations can be markedly increased by the administration of oestradiol to either ovariectomised rats (Murphy et al. 1988) or pigs (Simmen et al. 1990). Furthermore, Stevenson et al. (1994) showed that in sheep IGF-I mRNA expression was highest at oestrus and strongly correlated with oestrogen receptor protein levels. In the present study, IGF-I mRNA expression in the sub-epithelial stroma was highest around oestrus and lowest during the early and late luteal phases with a minor peak on day 10. Ohtani et al. (1996) previously reported a similar pattern of IGF-I protein expression in the bovine uterine stroma as determined by immunocytochemistry. Collectively, these results suggested that uterine IGF-I mRNA expression in the cow may be up-regulated by oestradiol. However, Geisert et al. (1991) observed no changes in endometrial IGF-I mRNA expression throughout the oestrous cycle as determined by Northern 

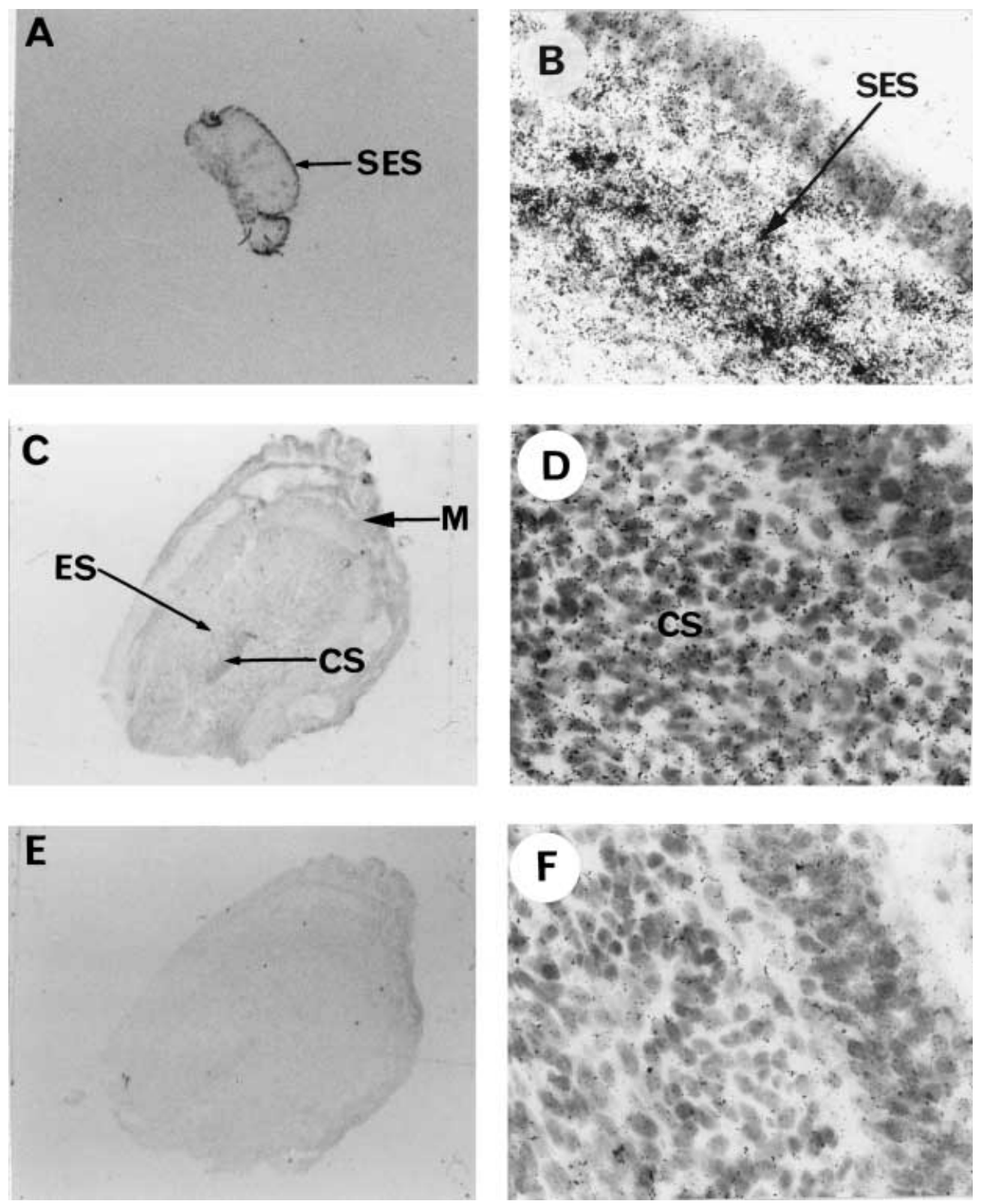

Figure 8 The localisation of IGFBP-3 in the bovine endometrium throughout the oestrous cycle (A and B) and on day 16 of pregnancy $(C$ and $D)$. These sections were probed with antisense oligonucleotides.

(E and F) Control sections probed with the corresponding IGFBP-3 sense mRNA. (A, C and E) Photographs of complete uterine cross-sections from autoradiographs; (B, D and F) show sections of uterine horn coated with photographic emulsion and counterstained with haematoxylin and eosin. The strongest expression of IGFBP-3 mRNA in the endometrial biopsies was found in the sub-epithelial stroma (SES) whereas in the day 16 PREG cow (except one non-pregnant cow, not shown) IGFBP-3 mRNA was confined to the endometrial stroma (ES), caruncular stroma $(\mathrm{CS})$ and myometrium (M). Magnification $\times 6(\mathrm{~A}) ; \times 2(\mathrm{C}$ and $\mathrm{E}) ; \times 1300(\mathrm{~B}$, $\mathrm{D}$ and $\mathrm{F})$.

blot hybridisation, which would have combined tissue from most endometrial regions. Thus the cyclical regulation of IGF-I mRNA expression may be limited to the sub-epithelial stroma.
The effect of pregnancy on IGF-I mRNA expression in the bovine endometrium is equivocal. Kirby et al. (1996) reported higher levels on day 17 of pregnancy, while Geisert et al. (1991) showed that pregnancy had no effect 

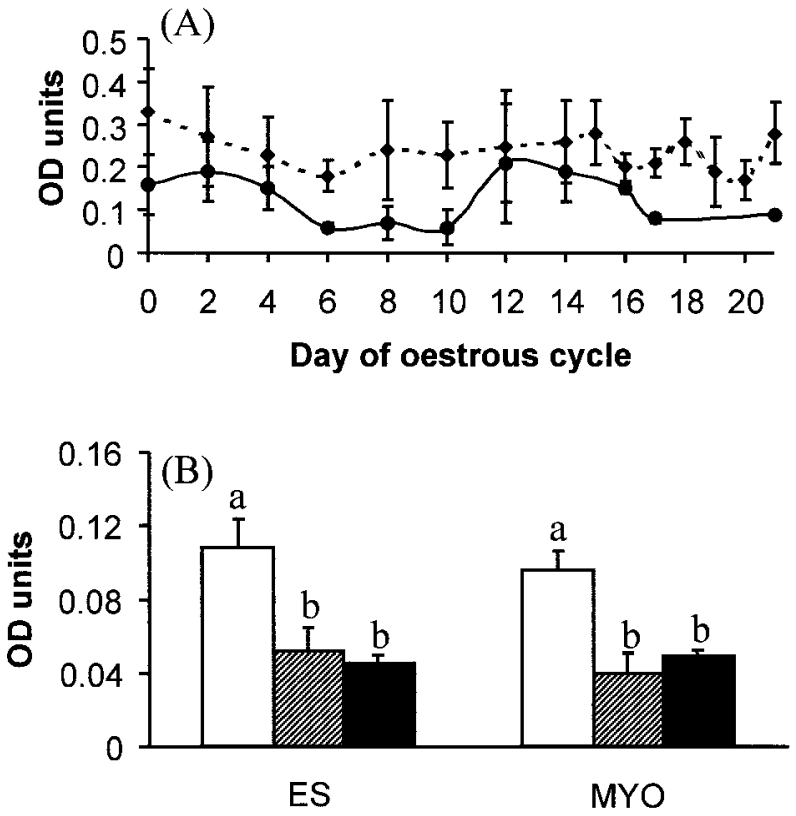

Figure 9 The concentration of IGFBP-3 mRNA in the bovine endometrium: (A) throughout the oestrous cycle and (B) on day 16 of pregnancy. Values are mean OD units \pm S.E.M. (A) Concentrations of IGFBP-3 mRNA in the sub-epithelial stroma (continuous line, $\mathbf{)}$ ) and in the superficial glands (dotted line, $\bullet$ ) of bovine endometrial biopsy samples throughout the oestrous cycle ( $n=3-4$ per time point). There were no significant differences with time in any region. (B) Expression of IGFBP-3 mRNA in the bovine uterus from CONT (open bars; $n=9$ ), INP (hatched bars; $n=5$ ) and PREG (solid bars; $n=15$ ) cows. The expression of IGFBP-3 mRNA was significantly $(a>b ; P<0 \cdot 01)$ lower in the PREG and INP compared with the CONT group. $\mathrm{ES}$, endometrial stroma; MYO, myometrium.

on endometrial IGF-I expression on days 10, 15 and 18. In this study, we observed that $60 \%$ of the PREG cows expressed IGF-I mRNA in the sub-epithelial stroma compared with only $20 \%$ of the INP group and $33 \%$ of the CONT group. These differences were not, however, significant and more studies are required to elucidate the exact regulation of IGF-I mRNA during early pregnancy.

The main site of IGF-II mRNA production in the endometrium was the caruncular stroma, which is the area of embryonic attachment in ruminants. Stevenson et al. (1994) similarly reported a strong expression of IGF-II mRNA in the caruncles. Collectively, these results would support a role for IGF-II in the preparation of the caruncle for pregnancy. Geisert et al. (1991) reported an increase in IGF-II mRNA expression in the bovine endometrium on days 15 and 18 of pregnancy, but there was no such increase in the uterine luminal fluid and they hypothesised that IGF-II expression was regulated by the conceptus. Because not all sections had a caruncle present, it is difficult to say whether or not the presence of an embryo had any effect on the caruncular IGF-II mRNA in this study. However, the expression of IGF-II mRNA in the endometrial stroma and myometrium was lower in the PREG cows compared with the CONT.

IGF-1R mRNA was localised to the epithelial cells throughout the oestrous cycle and on day 16 of pregnancy with expression higher in the deep glands than the luminal epithelium. IGF-1R mRNA was also localised to the caruncular stroma and myometrium although at lower levels. A similar distribution of uterine IGF-1R mRNA and IGF-I binding (detected by autoradiography) during early pregnancy has been reported for sheep (Stevenson et al. 1994, Reynolds et al. 1997a). IGF-1R mRNA was also localised to the glandular epithelium in baboons during the luteal phase and early pregnancy (Hild-Petito et al. 1994). This would support a role for either systemic or local IGF-I and -II in the stimulation of glandular secretions, on which the ruminant embryo is dependent during the pre-implantation period. The presence of IGF-1R mRNA in the caruncular stroma would suggest an autocrine action for IGF-II in the proliferation of the caruncle in embryonic attachment. The expression of IGF-1R mRNA was not affected by either hormonal or pregnancy status. Similarly, in sheep and pigs IGF-1R mRNA was expressed throughout the oestrous cycle and early pregnancy (Hofig et al. 1991, Stevenson et al. 1994). This would suggest that IGF-1R mRNA in vivo was constituitively expressed in the bovine uterus.

The expression of IGFBP-1 mRNA was confined to the luminal epithelium. A similar localisation has been reported by in situ hybridisation in cows using a bovine riboprobe (Keller et al. 1998) and in sheep by both in situ hybridisation (Osgerby et al. 1999) and immunocytochemistry (Waites et al. 1990). IGFBP-1 mRNA expression was tightly regulated throughout the oestrous cycle, with low expression at oestrus and high expression from days 12 to 16 . Similarly in other species higher levels of IGFBP-1 mRNA have been found during the luteal phase of the ovarian cycle compared with the follicular phase (Cann et al. 1998 (sheep), Fazleabas et al. 1989 (baboon), Ghahary et al. 1993 (rats), Zhou et al. 1994 (humans)). Since high endometrial IGFBP-1 levels are observed when progesterone levels are high and the human IGFBP-1 gene contains a progesterone response element, it has been suggested that progesterone regulates IGFBP-1 expression in the endometrium (Lee et al. 1997, Tseng et al. 1997). In the present study, IGFBP-1 mRNA was up-regulated 6 days after plasma progesterone concentrations began to rise. We have previously reported that progesterone receptor mRNA concentrations are high from oestrus to day 8 and then progesterone receptor mRNA levels are up-regulated again on day 16 and continue to rise back to oestrus levels (Robinson et al. 1998). This suggested that when progesterone receptor mRNA expression was down-regulated, IGFBP-1 mRNA expression was induced and that as progesterone receptor reappeared 
IGFBP-1 mRNA concentrations declined. It is unlikely that progesterone is the sole regulator since IGFBP-1 mRNA expression was also observed at oestrus. The exact role that progesterone plays in the regulation of bovine IGFBP-1 mRNA needs further investigation.

We have reported here that on day 16 , the uterine IGFBP-1 mRNA expression was higher in the PREG than in the CONT group. Other studies have shown similar increases in IGFBP-1 in pregnant animals compared with controls during the time of maternal recognition of pregnancy (cow, (Keller et al. 1998) and sheep (Waites et al. 1990, Cann et al. 1998)). In the present study, there was no luteolytic progesterone fall in the non-pregnant cows on day 16 (plasma progesterone levels in PREG $7 \cdot 4 \pm 0.6 \mathrm{ng} / \mathrm{ml}$; CONT $6.7 \pm 0.8 \mathrm{ng} / \mathrm{ml}$; INP $5.9 \pm 0.7 \mathrm{ng} / \mathrm{ml} ; P>0 \cdot 05$, Mann et al. 1996). Osgerby et al. (1999) previously reported that in unilaterally pregnant ewes, in which the uterus had been previously transected, IGFBP-1 mRNA levels were higher in the pregnant horn compared with the non-pregnant horn. Collectively, these results suggest that the pregnancy effect on IGFBP-1 mRNA expression was a local embryonic signal rather than a systemic one. Waites et al. (1990) hypothesised that since maximal endometrial IGFBP-1 and embryonic IFN- $\tau$ production coincided with each other, IFN- $\tau$ may stimulate IGFBP-1 production. Further studies need to be carried out to see whether this embryonic signal is IFN- $\tau$.

The localisation of IGFPB-2 mRNA expression to the sub-epithelial stroma underlying the luminal epithelium agreed with previous studies in the cow using a riboprobe generated from a rat cDNA (Keller et al. 1998) and sheep (Reynolds et al. 1997a). In cows, it has been shown that endometrial IGFBP-2 mRNA expression increased during the late luteal phase in both cyclic and non-pregnant animals, although pregnancy had no effect (Geisert et al. 1991, Keller et al. 1998). In the present study on day 16, only $20 \%$ of PREG animals expressed detectable levels of IGFBP-2 mRNA in the sub-epithelial stroma compared with $80 \%$ of the INP group and $43 \%$ of the CONT cows. This suggested that the conceptus may suppress IGFBP-2 mRNA expression and thereby increase the bioavailability of the IGFs required for embryonic development.

In the endometrial biopsy samples, IGFBP-3 mRNA was present in the sub-epithelial stroma, luminal and superficial glands, whereas in the cows from Experiment 2, IGFBP-3 mRNA was absent from these regions. In both experiments, IGFBP-3 mRNA was present in the endometrial and caruncular stroma. The difference in the localisation of IGFBP-3 mRNA between the two groups may be explained by the differences in lactational or nutritional status of the animals. IGFBP-3 mRNA has been localised to the stromal cells juxtaposed to the luminal epithelium in rats (Girvigian et al. 1994, Cerro \&
Pintar 1997) and to the luminal epithelium and caruncular stroma in sheep (Reynolds et al. 1997a). There was no significant change in the expression of endometrial IGFBP-3 mRNA throughout the oestrous cycle, which suggested that in cows endometrial IGFBP-3 mRNA was not regulated by ovarian steroid hormones. In rats, the regulation of IGFBP-3 mRNA is unclear with oestradiol reported to decrease uterine IGFBP-3 mRNA in ovariectomised rats (Molnar \& Murphy 1994), whereas Girvigian et al. (1994) reported the highest IGFBP-3 mRNA expression at oestrus. On day 16 of pregnancy, the expression of IGFBP-3 mRNA was significantly lower in the PREG group compared with the CONT but was not different from INP cows. Keller et al. (1998) similarly reported lower levels of IGFBP-3 mRNA in the pregnant endometrium. IGFBP-3 acts primarily as an inhibitor of IGF-induced mitogenesis; thus if the embryo can reduce IGFBP-3 expression, it may increase the mitogenic action of IGF on the endometrial stroma (Cerro \& Pintar 1997). IGFBP-3 was moderately expressed in the caruncular stroma on day 16 of pregnancy and is likely to modulate the action of IGF-II on the development of the caruncle. IGFBP-3 mRNA was also strongly expressed in the blood vessel wall and has been similarly localised in both sheep (Reynolds et al. 1997a) and cows (Keller et al. 1998). Thus IGFBP-3 may either act as a barrier to the infiltration of systemic IGF or aid the transport of systemic IGF to its target site.

The strongest expression of IGFBP-5 mRNA was in the inner ring of the myometrium, with pregnancy having no effect. IGFBP-5 mRNA has also been localised to the myometrium in rats (Girvigian et al. 1994, Cerro \& Pintar 1997) and sheep (Reynolds et al. 1997b). IGFBP-5 mRNA was also expressed in the caruncular stroma, although at low concentrations, with pregnancy having no effect. In sheep, IGFBP-5 mRNA was also expressed in the caruncular stroma, although at much higher concentrations (Reynolds et al. 1997b) suggesting that there may be a species difference. Unfortunately, the majority of the endometrial biopsy samples did not contain myometrium or caruncular stroma and thus we were unable to determine IGFBP-5 mRNA regulation throughout the oestrous cycle.

In conclusion, IGF-I mRNA was localised to the sub-epithelial stroma underlying the luminal epithelium and was maximal at oestrus, whereas IGF-II mRNA was located in the caruncular stroma. Locally produced or systemic IGF-I and -II could therefore act on the IGF-1R in the glandular and luminal epithelium and caruncles to influence glandular activity and caruncular development. Their actions would be modulated by the IGFBPs. Expressions of IGFBP-1, -2 and -3 were all influenced by the presence of an embryo but only IGFBP-1 was regulated during the oestrous cycle. Future work is required to determine how this system is influenced by maternal nutrition. 


\section{Acknowledgements}

The authors thank the Ministry of Agriculture, Fisheries and Food and the Milk Development Council for financial support. The authors also thank Dr Jim Craigton, University of Nottingham, for his critical advice on the statistics. We also thank all the animal technicians at Sutton Bonington for the care of the animals and their help in the collections of the tissue and Mrs Barbara Wilsmore for the preparation of the photographs.

\section{References}

Bourner MJ, Busby WH, Siegel NR, Krivi GG, McCusker RH \& Clemmons DR 1992 Cloning and sequence determination of bovine insulin-like growth factor binding protein-2 (IGFBP-2): comparison of its structural and functional properties with IGFBP-1. Journal of Cellular Biochemistry 48 215-226.

Cann CH, Fairclough RJ, Browne CA \& Gow CB 1998 Uterine luminal content of insulin-like growth factor (IGF)-I and endometrial expression of mRNA encoding IGF-binding proteins 1 and 2 during oestrous cycle and early pregnancy in the ewe. Reproduction, Fertility, and Development 10 155-163.

Cerro JA \& Pintar JE 1997 Insulin-like growth factor binding protein expression in the pregnant rat uterus and placenta. Developmental Biology 184 278-295.

Farin CE, Imakawa K, Hansen TR, McDonnell JJ, Murphy CN, Farin PW \& Roberts RM 1990 Expression of trophoblastic interferon genes in sheep and cattle. Biology of Reproduction $\mathbf{4 3}$ 210-218.

Fazleabas AT, Verhage HG, Waites G \& Bell SC 1989 An insulin-like growth factor binding protein (IGFBP) in the baboon (Papio anubis) endometrium: synthesis, immunohistochemical localization and hormonal regulation. Endocrinology 124 2331-2329.

Geisert RD, Lee CY, Simmen FA, Zavy MT, Fliss AE, Bazer FW \& Simmen RCM 1991 Expression of messenger RNAs encoding insulin-like growth factor-I, -II and insulin-like growth factor binding protein-2 in bovine endometrium during the estrous cycle and early pregnancy. Biology of Reproduction 45 975-983.

Ghahary A, Luo J \& Murphy LJ 1993 Expression and regulation of insulin-like growth factor binding protein-1 in the rat uterus throughout the estrous cycle. Molecular and Cellular Biochemistry 124 43-49.

Girvigian MR, Nakatani A, Ling N, Shimasaki S \& Erickson GF 1994 Insulin-like growth factor binding proteins show distinct patterns of expression in the rat uterus. Biology of Reproduction $\mathbf{5 1}$ 296-302.

Hild-Petito S, Verhage HG \& Fazleabas AT 1994 Characterization, localization and regulation of receptors for insulin-like growth factor $\mathrm{I}$ in the baboon uterus during the cycle and pregnancy. Biology of Reproduction $\mathbf{5 0}$ 791-801.

Hofig A, Michel FJ, Simmen FA \& Simmen RCM 1991 Constitutive expression of uterine receptors for insulin-like growth factor-I during the peri-implantation period in the pig. Biology of Reproduction 45 533-539.

Hossner KL, McCusker RH \& Dodson MV 1997 Insulin-like growth factors and binding proteins in domestic animals. Animal Science 64 $1-15$.

Jones JI \& Clemmons DR 1995 Insulin-like growth factors and their binding proteins: biological actions. Endocrine Reviews 16 3-34.

Jones JI, Gockerman A, Busby WH, Wright G \& Clemmons DR $1993 a$ Insulin-like growth factor binding protein 1 stimulates cell migration and binds to the $\alpha_{5} \beta_{1}$ integrin by means of its Arg-GlyAsp sequence. Proceedings of the National Academy of Sciences of the USA 90 10553-10557.
Jones JI, Gockerman A, Busby WH, Camacho-Hubner C \& Clemmons DR $1993 b$ Extracellular matrix contains insulin-like growth factor binding protein-5: potentiation of the effects of IGF-I. Journal of Cell Biology 121 679-687.

Keller ML, Roberts AJ \& Siedel GE 1998 Insulin-like growth factor binding proteins in the uterus and embryos during early embryonic elongation in cattle. Biology of Reproduction 59 632-642.

Kirby CJ, Thatcher WW, Collier RJ, Simmen FA \& Lucy MC 1996 Effects of growth hormone and pregnancy on expression of growth hormone receptor, insulin-like growth factor-I and insulin-like growth factor binding protein-2 and -3 genes in bovine uterus, ovary and oviduct. Biology of Reproduction 55 996-1002.

Ko Y, Lee CJ, Ott TL, Davis MA, Simmen RCM, Bazer FW \& Simmen FA 1991 Insulin-like growth factors in sheep uterine fluids: concentrations and relationship to ovine trophoblastic protein-1 production during early pregnancy. Biology of Reproduction 45 135-142.

Kruip TAM, Meijer GAL, Rukkwamsuk T \& Wensing T 1998 Effects of feed in the dry period on fertility of dairy cows post partum. Reproduction in Domestic Animals 33 165-168.

Lee PDK, Giudice LC, Conover CA \& Powell DR 1997 Insulin-like growth factor binding protein-1: recent findings and new directions. Proceedings of the Society for Experimental Biology and Medicine 216 319-357.

Mann GE \& Lamming GE 1994 Use of repeated biopsies to monitor endometrial oxytocin receptors in cows. Veterinary Record 135 403-405.

Mann GE, Mann SJ \& Lamming GE 1996 The inter relationship between the maternal hormone environment and the embryo during the early stages of pregnancy in the cow. Journal of Reproduction and Fertility. Abstract Series 1755.

Molnar P \& Murphy LJ 1994 Effects of oestrogen on rat uterine expression of insulin-like growth factor binding proteins. Journal of Molecular Endocrinology 13 59-67.

Moser DR, Lowe WL, Dake BL, Booth BA, Boes M, Clemmons DR \& Bar RS 1992 Endothelial cells express insulin-like growth factor binding proteins 2 to 6. Molecular Endocrinology 6 1805-1814.

Murphy LJ, Murphy LC \& Friesen HG 1988 Estrogen induces insulin-like growth factor-I expression in the rat uterus. Molecular Endocrinology 1 445-450.

Ohtani S, Okuda K, Ohtani M \& Yamada J 1996 Immunohistochemically determined changes in the distribution of insulin-like growth-I (IGF-I) and epidermal growth factor (EGF) in the bovine endometrium during the estrous cycle. Journal of Veterinary Medical Sciences 58 1211-1217.

O'Mahoney JV \& Adams TE 1989 Nucleotide sequence of an ovine insulin-like growth factor II cDNA. Nucleic Acids Research 175392.

Osgerby JC, Reynolds TS \& Wathes DC 1999 Expression of insulinlike growth factor binding protein-1 (IGFBP-1) in the ovine uterus throughout the oestrous cycle and early pregnancy. Journal of Endocrinology 162 279-287.

Peters AR 1996 Embryo mortality in the cow. Animal Breeding Abstracts 64 587-598.

Reynolds TS, Stevenson KR \& Wathes DC 1997a Pregnancy specific alterations in the expression of insulin-like growth factor (IGF) system during early placental development in the ewe. Endocrinology 138 886-897.

Reynolds TS, Wathes DC, Aitken RP \& Wallace JM 19976 Expression of insulin-like growth factor binding protein-5 (IGFBP-5) in the pregnant ovine uterus. Journal of Reproduction and Fertility. Abstract Series 19124.

Robinson RS, Mann GE, Wathes DC \& Lamming GE 1998 Oxytocin, oestrogen and progesterone receptor mRNA expression in the bovine endometrium throughout the oestrous cycle. Journal of Reproduction and Fertility. Abstract Series 2197.

Shimasaki S \& Ling N 1991 Identification and molecular characterization of insulin-like growth factor binding proteins (IGFBP-1, $-2,-3,-4,-5$ and -6). Progress in Growth Factor Research 3 243-266. 
Simmen RCM, Simmen FA, Hofig A, Farmer SJ \& Bazer FW 1990 Hormonal regulation of insulin-like growth factor gene expression in pig uterus. Endocrinology 127 2166-2174.

Sneyers M, Kettmann R, Massart S, Renaville R, Burny A \& Portelle D 1991 Cloning and characterisation of a cDNA encoding the bovine insulin-like growth factor binding protein 1 (bIGFBP-1). Journal of DNA Sequencing and Mapping 6 407-408.

Spratt SK, Tatsuna GP \& Sommer A 1991 Cloning and characterization of bovine insulin-like growth factor binding protein-3 (bIGFBP-3). Biochemical and Biophysical Research Communications 177 $1025-1033$

Stevenson KR, Gilmour RS \& Wathes DC 1994 Localization of insulin-like growth factor-I (IGF-I) and -II messenger ribonucleic acid and type 1 IGF receptor in the ovine uterus during the oestrous cycle and early pregnancy. Endocrinology 134 1655-1664.

Thissen J-P, Ketelslegers J-M \& Underwood LE 1994 Nutritional regulation of the insulin-like growth factors. Endocrine Reviews $\mathbf{1 5}$ 80-101.

Tseng L, Gao J, Mazella J, Zhu HH \& Lane B 1997 Differentiationdependent and cell-specific regulation of the hIGFBP-1 gene in human endometrium. Annals of the New York Academy of Sciences 828 27-37.

Ullrich A, Gray A, Tam AW, Yang-Feng T, Tsubokawa M, Collins C, Henzel W, LeBon T, Kathuria S, Chen E, Jacobs S, Francke U, Ramachandran J \& Fujita-Yamaguchi Y 1986 Insulin-like growth factor-I receptor primary structure: comparison with insulin receptor suggests structural determinants that define functional specificity. EMBO Journal 5 2503-2512.

Waites GT, Whyte A \& Bell SC 1990 Localization of antigen defined by a monoclonal antibody to human $32-\mathrm{kDa}$ insulin-like growth factor binding protein in the sheep uterus at pre-implantation stages of pregnancy. Placenta 11 23-40.

Wathes DC, Reynolds TS, Robinson RS \& Stevenson KR 1998 Role of insulin-like growth factor system in uterine function and placental development in ruminants. Journal of Dairy Science $\mathbf{8 1}$ $1778-1789$.

Watson AJ, Hogan A, Hahnel A, Weimer KE \& Schultz GA 1992 Expression of growth factor ligand and receptor in the periimplantation bovine embryo. Molecular Reproduction and Development 31 87-95.

Wong EA, Ohlsen SM, Godfedson JA, Dean DM \& Wheaton JE 1989 Cloning of ovine insulin-like growth factor-I cDNA: heterogeneity in the mRNA population. DNA 8 649-657.

Zhou J, Dsupin BA, Giudice LC \& Bondy CA 1994 Insulin-like growth factor system gene expression in human endometrium during the menstrual cycle. Journal of Clinical Endocrinology and Metabolism 79 1723-1734.

Received 23 March 1999

Revised manuscript received 29 November 1999 Accepted 11 January 2000 